\title{
Knowledge Creation on Edible Vaccines
}

\author{
Micaela Martins ${ }^{1}$, Madalena Costa ${ }^{1}$, Marta Gonçalves ${ }^{1}$, Sandra Duarte ${ }^{1}$ and Manuel Au- \\ Yong-Oliveira ${ }^{1,2}$ \\ ${ }^{1}$ Department of Economics, Management, Industrial Engineering and Tourism, University of \\ Aveiro, Aveiro, Portugal \\ ${ }^{2}$ INESC TEC, GOVCOPP, Portugal \\ micaelamartins@ua.pt \\ madalenatcosta@ua.pt \\ martasgoncalves@ua.pt \\ sandrapad@ua.pt \\ mao@ua.pt
}

\begin{abstract}
In this paper we delve into the health sector and explore the way vaccines might change in the near future. As new challenges emerge, health professionals are faced with the need for innovative, effective answers to many issues, such as health-threatening viruses and diseases, that grow increasingly more complex, calling for new and practical solutions. Building on this framework, we have decided to address edible vaccines - a completely innovative and simpler way to administer vaccines - not only to understand if it is viewed in a favorable light but also to find out how the knowledge regarding these vaccines can be increased. After a thorough literature review, it became clear that the information about edible vaccines is not evident and easy to access. We then decided to apply a mixed methodology in our study, based on 15 interviews, in person and by email, addressing healthcare professionals, with the intent of gathering their experience and possible knowledge about vaccines. Additionally, an online survey was created and answered by 370 concerned citizens, in order to ascertain their knowledge and receptiveness to this matter. Hereupon, we concluded that, in both samples, there was very limited knowledge about these vaccines, it becoming obvious how important it is to transmit qualified information through accessible means, such as newscasts, scientific papers and magazines, health centers and hospitals, among others. Regarding the level of acceptance by the public in general, our results show that this innovation is dependent on its correct disclosure and propagation, since it is of great advantage and benefit for society. In sum, how the relevant knowledge (including proof of effectiveness) is managed and disseminated will be key.
\end{abstract}

Keywords: traditional vaccines, edible vaccines, field work, mixed methodology, Genetically modified organisms, GMOs

\section{Introduction}

In the range of management, innovation is the key that makes possible the delivery of new solutions. "Companies started to notice the increase in the demand for innovation to the point that it was too significant to be ignored and could not be left to chance" (Lajoso et al., 2020, p.437). Indeed, the pioneer in strategy research stated that "companies achieve competitive advantage through acts of innovation" (Porter, 1990, p.75). Innovation needs to be focused and face the needs of consumers (Carvalho, Roberto dos Reis and Beatriz Cavalcante, 2011). These same authors stand for the fact that every organization, regardless of the sector of activity, region or country, ought to prepare to innovate systematically and continuously. This brings us to the subject-matter, innovation regarding the health sector.

Over the past few decades, the health sector has gained increasing importance and appreciation (Ordeanu, 2018). As a consequence, there has been an attempt to invest in areas that allow for a greater development of this sector, namely in the area of technology (The Organisation for Economic Co-operation and Development, 2019).

At the same time, and despite the increase in average life expectancy that has been observed in recent years, the context in which we currently live, more distanced from nature and more sedentary, has led to the increasing importance of the health issue (Frumkin et al., 2017). Merchant (2013) claims sitting is the smoking of our generation, due to the fact that even most jobs require us to stay in front of a computer all day. On average, 9.3 hours a day are spent sitting, compared to only 7.7 hours spent sleeping.

The changes that have taken place in terms of lifestyle have also led to new health challenges, namely the emergence of new diseases resulting from a constantly changing world (Whitesides, 2014). A recent example of 
this change is the latest version of the COVID-19 virus, which has become a true global pandemic, and has reinforced the importance of vaccination (Gates, 2020).

In the face of this event of worldwide repercussions, the need for vaccination has been increasingly discussed, and, to date, there is still no vaccine available (Del Rio and Malani, 2020; Patlas, 2020).

Tragedies such as the one that the world is currently experiencing demonstrate the need to invest in the creation and development of vaccines and reinforce the fact that it is essential to have laboratories capable of responding to these events (Gates, 2020).

With this article we try to present what is a new reality in the field of vaccination: edible vaccines. Through this theme, we compare this new reality with the traditional vaccines already known, explaining the different advantages and disadvantages associated with each one. Our aim is also to perceive the public opinion on the matter, the opinion of the people linked to the health area regarding these two types of vaccines and possible recommendations in the development of edible vaccines.

\section{Literature Review}

\subsection{Knowledge Management and Creation}

In order to innovate, it becomes essential to apply all current knowledge to create new knowledge. Thus, knowledge management (KM), meaning the complex process of identification, attainment, development, distribution, use and protection of precious knowledge, presents itself as an important competitive advantage for companies (Melo, 2019). According to Choi and Lee (2002), if a company fails to continuously create knowledge, the unavoidable result is poor performance.

In the competitive environment of companies, knowledge management is a central element in order to guarantee that a company performs an analysis of knowledge and its competences (North and Kumta, 2018). A company's knowledge is constantly being complemented with new knowledge, resulting from the company's actions and the pressure from the external environment (Grimsdottir and Edvardsson, 2018).

As mentioned by Little and Deokar (2016), due to the importance of knowledge management, organizations are now progressively trying to understand the knowledge assets within the company. Consequently, organizations have been aiming to align their knowledge management strategies with their business process management (Little and Deokar, 2016).

Different factors will condition the knowledge creation and management process (Abubakar, et al., 2019). The authors point out some of these factors, such as organizational structure, organizational culture and information technology.

However, the knowledge creation and management process has been greatly altered by the arrival of the digital age, offering new opportunities and creating new challenges, leading to the consequent emergence of new business models (North and Kumta, 2018).

\subsection{Traditional vaccines}

\subsubsection{Vaccines: concept}

Vaccines emerged, and are still used today, with the ultimate goal of reducing the existence of some diseases and, as a consequence, reducing mortality rates (Subtil and Vieira, 2011). For this reason, it is considered one of the most effective ways to promote public health (Fonseca et al., 2018; Orensteina and Ahmedb, 2017; Pinto, Matta and Da-Cruz, 2011), leading to a 73\% decrease in mortality worldwide, preventing between 2 and 3 million deaths annually (World Health Organization, 2019; Santos and Hespanhol, 2013). Consequently, vaccination is considered to be a strategic action for different countries, being essential for national security (Ordeanu, 2018).

Vaccines consist of preparations created through a specific process and composed by a set of substances that, when administered, cause the body to create immunity against some agents (Pinto, Matta and Da-Cruz, 2011; Santos and Hespanhol, 2013). Most vaccines are administered through syringes and needles (Pinto, Matta and Da-Cruz, 2011), this task being mainly performed by nurses (Subtil and Vieira, 2011). 


\subsubsection{Vaccines: advantages and disadvantages}

The efficiency of a vaccine, when it comes to the prevention of diseases, can depend on both the vaccine being effective and its correct administration to individuals who are able to respond to it (Orenstein et al., 1985).

With this in mind, and according to a generally divided opinion by the public when it comes to this matter, we can all agree that vaccines have advantages and disadvantages. After a careful literature review on this matter, we realized that the benefits that come from this prevention system are, clearly, bigger than its disadvantages and challenges. Perhaps they only need to be updated and be more innovative.

When it comes to the so-called advantages, "vaccination is the most successful application of immunological principles to human health" (Khan, 2013, p. 26). The same author keeps on substantiating that these diseases represent a major global problem. This can only mean that their prevention must be a public health priority. Live vaccines have been administered to hundreds of millions of individuals during the past decade, and their results are extremely reliable and efficient (Melnick, 1978).

On the other hand, the possibility of adverse effects (Schatzmayr, 2003) along with the fact that injections can be painful and, in some cases, expensive, involving needles, syringes and a trained professional to administer them (Pinto, Matta and Da-Cruz, 2011), appear to be some of the disadvantages that can be found when analyzing the traditional vaccines. Additionally, there are several diseases caused by pathogens, which enter our body through a mucous surface, such as the gastro-intestinal or the respiratory tract. This means an injection is not the standard way of entry of most pathogens, as vaccination is meant for (Pinto, Matta and Da-Cruz, 2011).

\subsubsection{Vaccines: "The (not) global acceptance"}

In Portugal, the National Vaccination Program came into force in 1965, providing free vaccines to the population (Subtil and Vieira, 2011; Fonseca et al., 2018). Since 2015, vaccines against thirteen different diseases have been included in this plan (Fonseca et al., 2018).

Despite the importance of vaccination, there is still a part of the world population that is not vaccinated, including millions of children (Fonseca et al., 2018; World Health Organization, 2019). This occurs mainly in countries considered to be less developed (World Health Organization, 2019). At the same time, hesitation regarding vaccination, which is largely due to the spread of wrong information, has been increasing (Orensteina and Ahmedb, 2017; Pinto, 2018).

In Portugal, vaccination is not mandatory, so the individual, or his, or her, representative, can refuse it (Santos and Hespanhol, 2013; Fonseca et al, 2018; Pinto, 2018). However, vaccination is strongly recommended by health professionals (Pinto, 2018).

Despite this possibility, a study carried out in Portugal in 2018 concluded that there is a low number of parents refusing vaccination (Fonseca et al, 2018; Pinto, 2018). According to recent studies, the Portuguese regions with the lowest occurrence of vaccination are the Autonomous Regions (Machado et al., 2019).

The main problem with refusing vaccination is that it is an individual act and, as such, only leads to the protection of an entire community when each individual chooses to do so, thereby reducing the spread of disease in that population (Orensteina and Ahmedb, 2017). According to the same authors, this community protection ends up leading people who are not vaccinated, or cases in which the body did not have the expected reaction to the vaccine, to be protected indirectly, so greater vaccination coverage is essential.

\subsubsection{Genetically Modified Organisms}

Consumers are nowadays undoubtedly interested in the food they consume, particularly with regard to its origin and components (Wunderlich and Gatto, 2015). As a matter of science, genetically modified foods have become a controversial issue due to their potential impact on the human diet, existing patterns of food production, genetic diversity and the environment (Mclnerney, Bird and Nucci, 2004).

Genetically modified organisms (GMOs) are organisms in which the genetic material has been altered in a way that does not occur naturally by mating and/or natural recombination (Sun, 2018). GMOs are then used for various reasons, some of which are improved resistance of crops to herbicide, insects (Wunderlich and Gatto, 
2015) and diseases. At the same time, with this resource men can use natural resources in a more efficient way and it also contributes to the conservation of natural habitats, since with GMOs we can make the most of the existing arable land, preserving nearby habitats (Bayer, 2019). In 2018, the GMOs which were most cultivated worldwide were essentially cotton, soybeans and corn (Québec, 2020).

Public debate regarding the receptivity of GMOs in food production focuses on the controversy that originates in weighing over the risks to human health and the environment. The response of consumers to these risks can be volatile, as was seen in some protest actions in Europe (Nelson, 2001), where there is a low rate of adoption of genetically modified products and there is a greater inclination to pay for foods without GMOs than there is in America (Wunderlich and Gatto, 2015).

Despite all this, since the commercialization of GMOs began, the areas destined for its cultivation have undergone a notable evolution. According to Québec (2020), the United States is, currently, the leading producer of genetically modified foods, contributing with 73.1 million hectares of land and $40 \%$ of the global total cultivation of GMOs. The same author refers that this country is followed by Brazil (42.2 million hectares), Argentina (24.3 million hectares), India (11.6 million hectares) and Canada (11.6 million hectares). Many of the countries that contribute to the global production of Genetically Modified Organisms are industrial countries (Québec, 2020). At the same time, it is possible to affirm that most of these countries are developing countries that resort to GMOs because of their need to increase harvests (Wunderlich and Gatto, 2015).

Despite the apprehension displayed by public opinion, the World Health Organization endorses the idea: "GM foods currently available on the international market have passed safety assessments and are not likely to present risks for human health. In addition, no effects on human health have been shown as a result of the consumption of such foods by the general population." (World Health Organization, 2014).

\subsection{Edible vaccines}

\subsubsection{Edible vaccines concept, advantages and ethical aspects}

Vaccines have been the most powerful "weapon" against viruses and infections, preventing the risk of contagion and defending us from our many diseases (Criscuolo et al., 2019). However, as mentioned before, the traditional vaccines, despite having several advantages, have a number of important disadvantages. The goal, today, is to find innovative vaccines that are easier to administer and can target numerous pathogens in their various stages (Gunasekaran and Gothandam, 2020). In order to achieve this, edible vaccines are seen as the solution to the problems caused by traditional vaccines (Criscuolo et al., 2019). These new vaccines are cheaper than the old ones: they do not go through the purification and downstream process (Gunasekaran and Gothandam, 2020). Besides this, the same authors refer that they can be easy to preserve and to "scale up". This is undeniably impressive, considering that, as mentioned in the article, "the entire population of China could be vaccinated by producing edible vaccines in just 40 hectares of land" (Gunasekaran and Gothandam, 2020). According to the same authors, edible vaccines enable the organism to have an immunologic response merely by the consumption of genetically modified plants, including vegetables and fruits. This response is achieved through the activation of the mucosal immune response system (MIS), which is our first line of defense, since that is exactly where human pathogens start their infection (Gunasekaran and Gothandam, 2020).

Researchers introduce the desired gene into the plant, so it can produce the corresponding protein (Criscuolo et al., 2019; Gunasekaran and Gothandam, 2020). This transformation is carried out by a specific nonpathogenic virus or bacteria (Gunasekaran and Gothandam, 2020). There is almost no chance of contamination of humans by plants' pathogens since these are harmless to them (Criscuolo et al., 2019; Gunasekaran and Gothandam, 2020).

According to Gunasekaran and Gothandam (2020), edible vaccines can be produced in several plants or vegetables such as the banana, tobacco, potato, tomato, rice, etc. There are still edible algal vaccines that are very similar to the plant ones, however, they are easier to modify genetically (Gunasekaran and Gothandam, 2020).

These vaccines can contribute to the reduction of many diseases in underdeveloped countries where the conservation, transportation and administration of traditional vaccines is very complicated (Kurup and Thomas, 2019). 
Although they have many advantages, there is a problem related with "global approval" (Kurup and Thomas, 2019). It is crucial for people to be aware that edible vaccines are cost effective, efficient and safe, when compared with traditional vaccines (Kurup and Thomas, 2019). The same authors, already mentioned, believe that they can even guarantee a better prevention from diseases. Regulatory and GMP (Good Manufacturing Practice) requirements have to be the ethical base to develop these types of vaccines (Kurup and Thomas, 2019).

\subsubsection{Reasons to select certain plants}

Hence, certain targeted plants will be the ones chosen for their being appropriate to be modified genetically, in order to develop edible vaccines (Gunasekaran and Gothandam, 2020). The same authors argue that research and development are important tools to optimize the transformation process.

Furthermore, the plants chosen for this process have to be preserved for a long time without degrading, which is the case of cereals such as rice (Gunasekaran and Gothandam, 2020). Then, they need to have a short growth time, such as tobacco and tomato (Gunasekaran and Gothandam, 2020). Thereby, according to the same authors, fruits from trees cannot be used, since they grow slowly and take a long time to mature.

In fact, plants have a lot of advantages, but the most important one is that they can be easily mass produced, using various techniques (Gunasekaran and Gothandam, 2020). Micropropagation can be very important after the transformation process since plants grow in controlled conditions - "The technique of plant tissue culture is used for growing isolated plant cells, tissues and organs under axenic conditions (in vitro) to regenerate and propagate entire plants" (Iliev et al., 2010, p. 1).

\subsubsection{Related studies}

The "National Institute of Allergy and Infectious Diseases approved edible vaccine for its remarkable effect of immunogenicity in 1998". (Kurup and Thomas, 2019, p. 80)

Research associated with edible vaccines has been carried out since the end of the twentieth century (Kurup and Thomas, 2019). The same authors refer that, nowadays, in order to overcome certain fiscal restrictions, such as logistics and the transportation of traditional vaccines, edible ones are being developed to prevent malaria by the identification of three antigens. According to the same authors, measles and hepatitis $B$ edible vaccines are being created too. With regard to measles, according to Kurup and Thomas (2019), there are studies proving the presence of IgA antibodies in faecal samples of the animals that consumed these types of vaccines with the corresponding protein. Transgenic carrot and potato are the plants chosen for measles and hepatitis B edible vaccines, respectively (Kurup and Thomas, 2019). The same authors refer that even autoimmune diseases, such as type 1 diabetes, can be controlled by the consumption of a potato that contains insulin, maintaining insulin levels established. There are still many other edible vaccines developed against E.coli infection, through transgenic corn; cholera infection, by transgenic potatoes; and norovirus infection, using potato and tobacco as candidate plants (Kurup and Thomas, 2019).

\section{Methodology}

Our research study and research questions aim to address whether edible vaccines are both an acceptable and viable healthcare option. Are they viewed in a favourable light? What are the advantages and disadvantages of this innovative procedure? How might knowledge regarding these vaccines be increased?

Vaccines are vital to human survival, as the current pandemic regarding the new disease Covid-19 shows (World Health Organization, 2020). The resolution of the current global crisis is seen to be dependent on the creation of a vaccine to thus create immunity to the virus in the worldwide population. This is but one application of vaccines.

Hence, a literature review was performed, in order to gain crucial knowledge about the topic and its current implications worldwide, using the research databases available, such as Scopus and Academia, for example. We opted for the use of specific keywords, such as "vaccine", "administration", "edible", "advantages", "disadvantages" and "GMO". These words were used to reach some of the most important scientific evidence in this article.

The future of technological innovation is not as unpredictable as it might appear, but when the development of new technologies takes place, it can never be certain how the market will respond to it (Schilling, 2017). 
Therefore, we decided to perform a mixed methodology study, considering it was very important for this study to have the perspective of both the people who administer the vaccines (involving 15 interviews), and the people who receive them (a total of 370 answers were gathered). The first group it was intended would provide an indepth perspective on the subject of vaccines and edible vaccines, in particular; this data would be complemented by the "meanings and findings" of the survey (Saunders et al., 2016, p.173). The objective was that "mixed methods may allow for a greater diversity of views to inform and be reflected in the study" (Saunders et al., 2016, p.173). Greater confidence in our conclusions would result (Saunders et al., 2016), from using a mixed method, which is "an increasingly used and accepted approach to conducting business research and in the social sciences more generally" (Bryman and Bell, 2015, p.643).

Hence, an interview script was prepared for healthcare professionals experienced in the administration of vaccines, based on the previous literature review, and will be explained later in this segment of the article.

During the process of this study, a total of 25 nurses and pharmacists were contacted with the intent of gathering their experience and possible knowledge about vaccines, their implementation in the general population and this innovative method: edible vaccines. However, only 15 of those professionals replied to our contact and were interviewed, some in person and some by email (due to the COVID-19 pandemic we are facing at the time of writing) with an average duration of 15 minutes each, resulting in the conclusions laid out in sub-section 4.2 of this article.

In addition, as mentioned above, a survey was prepared and put out to the public, mainly via social media, meaning Facebook and identical platforms, since we wanted to get the largest and more diverse range of answers that we could. A total of 370 answers were received. This sample is mainly a convenience sample, since it was obtained from sharing it with the authors' acquaintances. This kind of sample, substantially more available to the researcher, is often used in exploratory studies, as it presents itself as a very useful tool for research, in order to reach a larger population and gather sufficient answers to enable interesting conclusions (Bryman and Bell, 2015). These authors suggest that valid conclusions can be based on an even sequence between a quantitative and qualitative framework (mixed method), as followed herein.

However, an effort was made in order to make the quantitative study as probabilistic as we could: once we were short on responses from the older age group, the survey was placed on Facebook groups for citizens over 65 years old. Additionally, a small percentage of individuals that are not a part of the convenience sample, were contacted personally, in cafes and other public areas, with the purpose of gaining a more diverse response rate.

In this survey, we decided to ask for basic personal information from our respondents, such as their age, gender, occupation, geographic location and the dimension of the place of residence (1-5), so that we could later analyse the data and find possible links between the groups of people and their answers. We then proceeded with a question referring to their knowledge about GMO (Genetically Modified Organisms) (6) and inquired whether the respondents were in favor or against them (7). These answers would be the premise from which we would be able to determine if knowing about the GMO could influence the participants' opinions on edible vaccines, as well as understand if their opinion on these organisms was biased by the media coverage of the issue or not (8). The following question present in this survey inquired about the possible need of more reliable information on the subject (9). We then chose to question the respondents regarding their view on traditional vaccines (10) hoping to understand if they had somehow struggled with their administration (11) or to highlight some of its various disadvantages (12). The last three questions of our survey aimed to perceive the participants' view on edible vaccines. First of all, we tried to understand if they had, in fact, understood what edible vaccines were (13). We took the liberty of providing a brief description of them in the beginning of our survey, in order to avoid misunderstandings or answers lacking foundation. We also inquired about their willingness to take edible vaccines (14). Our last question aimed to gather suggestions for a better understanding of this new way of vaccine administration (15), since we believe it might be one of the main obstacles in their implementation.

As we previously mentioned, in order to expand this exploratory study to health professionals and get their opinions on this subject, we developed an interview script based on essential issues related to edible vaccines and their work experience. Summing a total of six questions, we first chose to ask the respondents about their age, gender, occupation and where they worked. Then, we inquired the participants about their knowledge or unawareness regarding edible vaccines (1). If the answer to this question was a negative one, we proceeded in explaining this new concept. The following question aimed to understand whether the respondents were in 
favor or against them (2), as well as the motive for their decision. We then asked about the main struggles they found in administering traditional vaccines (3); whether they found these new vaccines would be easily accepted by the general public (4); what did they consider a main obstacle in the implementation of the edible vaccines (5). Our last question was related to their opinion or suggestion regarding this possibility in the future (6).

\section{Results and discussion}

As mentioned above, after our research and field work, we received 370 and 15 answers from our online survey and our interviews, respectively.

\subsection{Online survey}

Concerning the answers from our survey, we noticed that $77,8 \%$ of them were from people aged less than or equal to 24 years old, followed by $10,8 \%$ from $25-45$ year olds, 9,2\% from $46-65$ year olds and 2,2\% from people older than 65. It was expectable to have more answers from young people, since our methodology focused on social networks, like Facebook. However, this is important since this type of vaccine will probably be implemented in the future, so it is crucial to know their opinion about this innovation. Therefore, students were our most representative percentage, $75,1 \%$, considering the question regarding the respondents' occupation. As we can see in figure 1 most of our responses were also answered by women, representing a total of $77 \%$.

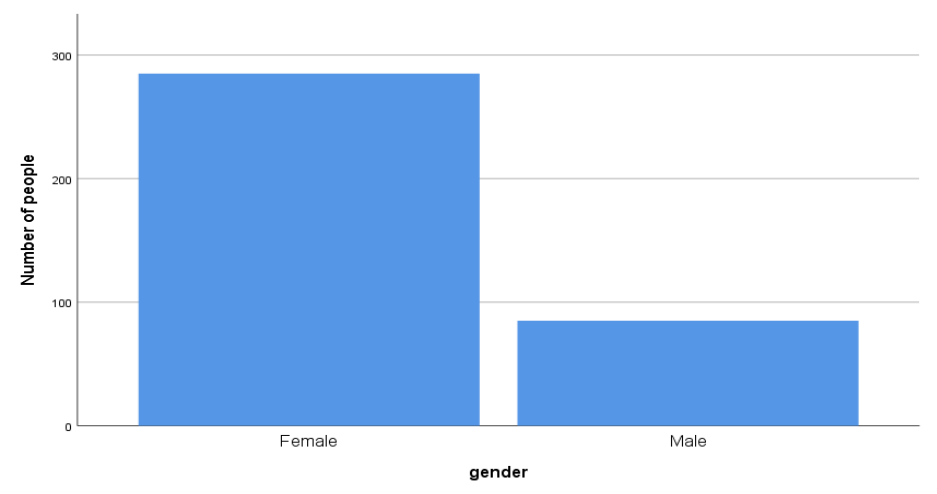

Figure 1: Frequency of people by gender - Q2

Observing figure 2, we can notice that we received answers from all of the geographic localizations in Portugal: the North (45\%), Center (47,6\%), South $(4,6 \%)$ and the Islands $(1,9 \%)$. We even gathered data from distinct types of locations: cities $(55,1 \%)$, towns $(21,9 \%)$ and villages $(23 \%)$.
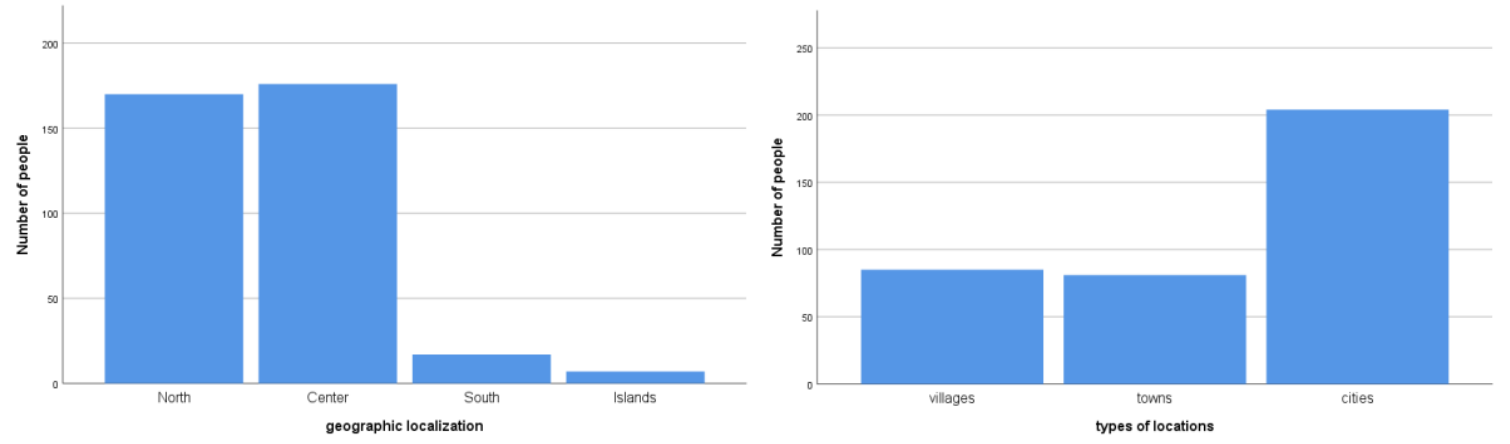

Figure 2: Frequency of people by geographic localization-Q4- (left) and types of locations-Q5- (right)

After analysing what kind of people answered our online survey, it is extremely important to see the answers to the questions related to our main theme: edible vaccines. Thus, regarding our sixth question about the knowledge acquired about GMOs (Genetically Modified Organisms), the answers were dispersed. Around 10,5\% of them chose the answer number 5 , having advanced knowledge about it. Then $29,5 \%$ answered the number $4 ; 33,8 \%$ the number $3 ; 11,9 \%$ the number 2 and $14,3 \%$ the number 1 , having a limited knowledge about GMOs.

Although more than $50 \%$ of them know something about GMOs, it is extremely necessary to improve that knowledge. In order to confirm their existing knowledge, we elaborate questions 7, 8 and 9, related to their position on the matter: for or against GMOs; the influence of information in taking that position and the need for the transmission of more information, respectively. In fact, we obtained a percentage of $73,5 \%$ in favor and 
$26,5 \%$ against GMOs (table 1 ). Hence, in order to understand if this decision is influenced by social media or any other information that was transmitted, we got answers to question 7: 45,9\% answered "No"; 37,3\% "Perhaps" and 15,4\% "Yes". We also had 1,4\% saying that they had never heard anything about it (table 1).

Table 1: Intersection of values of question 7 and 8

\begin{tabular}{|c|c|c|c|c|c|c|}
\hline \multicolumn{7}{|c|}{ Number of people } \\
\hline & & \multicolumn{4}{|c|}{ Q8 } & \multirow[t]{2}{*}{ Total } \\
\hline & & Yes & No & Perhaps & $\begin{array}{l}\text { Never heard } \\
\text { anything } \\
\text { about GMOs }\end{array}$ & \\
\hline \multirow[t]{2}{*}{ Q7 } & In favor & 40 & 130 & 101 & 1 & 272 \\
\hline & Against & 17 & 40 & 38 & 3 & 98 \\
\hline \multicolumn{2}{|c|}{ Total } & 57 & 170 & 139 & 4 & 370 \\
\hline
\end{tabular}

Therefore, we can see that $47,8 \%$ of the sample that are in favor of GMOs, think that the information transmitted by the media had no influence in the decision made in question 7.

Concerning answers to question 9, we can conclude that it is crucial to transmit more information about GMOs, since these can play a relevant part in our future. In fact, $98,1 \%$ of the sample agree with that, and one person even said that "[better information] should be transmitted, instead of the demonization that is led by the media and in social networks".

Regarding data collected from question 10 (regarding views on traditional vaccines), we noticed that 95,8\% of the sample are in favor of traditional vaccines. According to the answers of question 11 (to understand if they had somehow struggled with traditional vaccine administration), this happened, despite $44,9 \%$ of them having answered the question with option number 1 , having no experience of any difficulty when administering that type of vaccine. $20 \%$ of the respondents opted for number $2 ; 18,6 \%$ number 3 , having some difficulty; $5,9 \%$ number 4 and $10,5 \%$ number 5 , having a huge difficulty (figure 3 ).

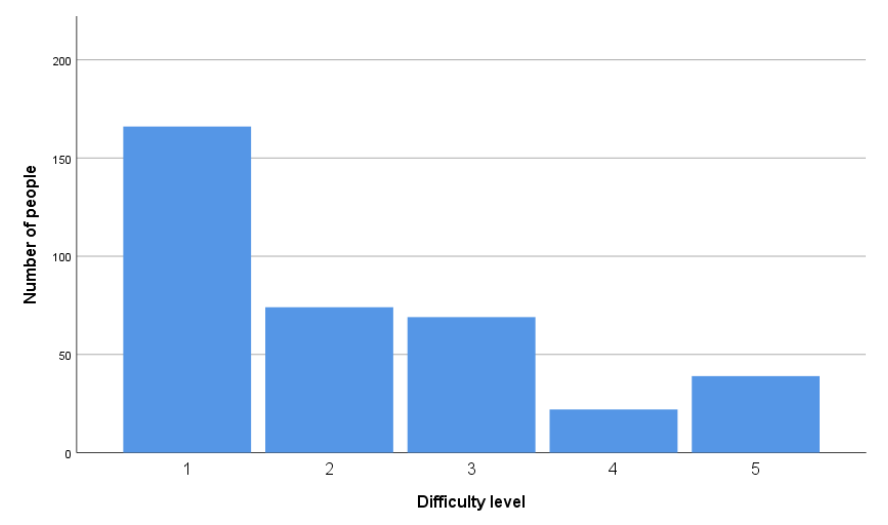

Figure 3: Frequency of people by difficulty level -Q11

Then, in order to analyse some motives related with those answers, we asked for suggestions regarding the disadvantages of traditional vaccines. We registered 161 answers and most of them are related to the pain caused by the needles of these vaccines, an element which causes both fear and panic in some people. Other motives are related to:

- the medical waste: vaccines can only be used once and then go to waste;

- $\quad$ the need for a qualified professional to administer the vaccine;

- the possible inflammation, swelling and scar left by the needle;

- the possibility of contamination through the needle;

- the dependency on good preservation and storage conditions;

- $\quad$ the related side effects;

- the travel to the administration site;

- the expensive cost: those that are not included in the national health plan. 
In relation to question 13 (to understand if they had, in fact, understood what edible vaccines were), 95,1\% of the sample understood the definition of edible vaccines. In order to know if people were willing to take the edible vaccines, we were able to gather the following answers: $4,9 \%$ of them chose the answer number 1 , which means they do not consider taking it; $8,4 \%$ choose number $2 ; 24,6 \%$ opted for number $3 ; 23,2 \%$ preferred number 4 and $38,9 \%$ decided for number 5 , having no problem in taking the edible vaccines (figure 4).

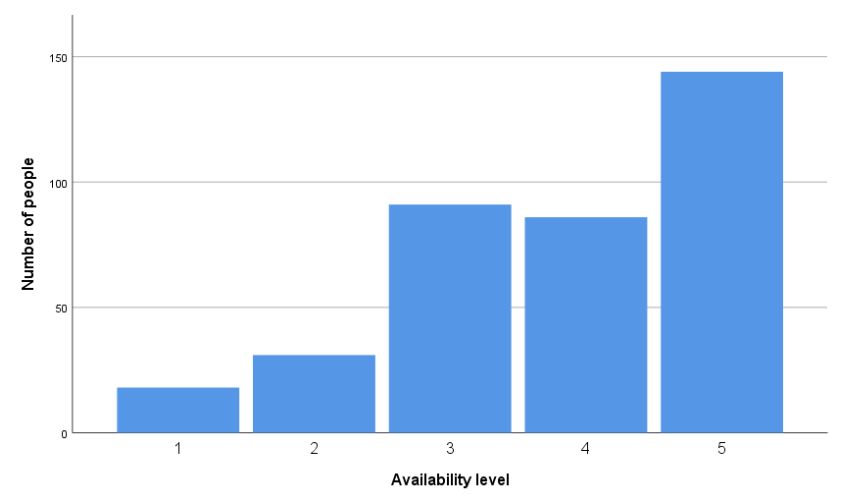

Figure 4: Frequency of people by availability level - Q14

This allows us to conclude that most people are available to consume this type of vaccine. Although these results are a step towards an easier implementation, we asked for suggestions on the subject. We were able to assemble 105 answers and the most addressed and important one is: providing information about edible vaccines, in numerous ways, like social media, health centers, hospitals, videos, lectures and leaflets, include it in education, articles and awareness programs. Other suggestions are more related with studies, underlining the need to do more of them to prove the efficiency and advantages of this type of vaccine. In short, people want to know, in detail, how these vaccines are produced and administered (information about the dosages, for example), what their advantages are over the old ones, how they work, their efficiency and side effects.

\subsubsection{Pearson's chi-squared test}

In this study, in some questions, we obtained answers rated from 1 to 5 . Thus, these values had to be grouped, in the chi-squared test, since this test only accepts values rated less than 5 . Hereupon, we considered answers 1 and 2 negative, creating a group, and answers 3, 4 and 5 positive, creating another group. Thus, we decided to, in SPSS, apply the chi-squared test ( $p$-value=0,05) between variables of these selected questions: $1,4,5,6$ (grouped), 7, 8, 11 (grouped) and 14 (grouped). In the article we will only show the entire procedure once, between the two most relevant variables. For the rest of the variables, we will have, at the end of this section, a table with the significance values obtained.

First of all, we formulated the hypotheses to test the independence of the variables under study: $\mathrm{HO}=$ the variables are independent $\mathrm{H} 1=$ the variables are dependent

Then, we developed a contingency table with the expected values and those obtained from the two selected variables.

Table 2: Contingency table between variables from questions 11 and 14

\begin{tabular}{|c|c|c|c|c|c|c|c|}
\hline \multicolumn{7}{|c|}{ Frequency } & \\
\hline & & \multicolumn{4}{|c|}{ Q14 - Level of availability (edible vaccine } & \multirow{2}{*}{\multicolumn{2}{|c|}{ Total }} \\
\hline & & \multicolumn{2}{|c|}{ Negative (No) } & \multicolumn{2}{|c|}{ Positive (Yes) } & & \\
\hline & & Score & $\begin{array}{l}\text { Expected } \\
\text { Score }\end{array}$ & Score & $\begin{array}{l}\text { Expected } \\
\text { Score }\end{array}$ & Score & $\begin{array}{l}\text { Expected } \\
\text { Score }\end{array}$ \\
\hline \multirow{2}{*}{$\begin{array}{l}\text { Q11 - Level of } \\
\text { difficulty } \\
\text { (traditional } \\
\text { vaccines) }\end{array}$} & $\begin{array}{l}\text { Negative } \\
\text { (No) }\end{array}$ & 38 & 32,9 & 201 & 206,1 & 239 & 239,0 \\
\hline & $\begin{array}{l}\text { Positive } \\
\text { (Yes) }\end{array}$ & 13 & 18,1 & 118 & 112,9 & 131 & 131,0 \\
\hline \multicolumn{2}{|l|}{ Total } & 51 & 51,0 & 319 & 319,0 & 370 & 370,0 \\
\hline
\end{tabular}


Finally, in SPSS, we applied a chi-squared test and the value of significance obtained was 0,111 , which is higher than the initial considered $p$-value. Thus, we cannot reject $\mathrm{HO}$, nor affirm something regarding the dependence or not of these variables.

The following table 3 presents the $p$-values/significance of all variables from the selected questions.

Table 3: P-values between the values/variables of the corresponding selected questions

\begin{tabular}{|c|c|c|c|c|c|c|c|c|}
\hline $\begin{array}{l}\text { Variables } \\
\text { / } \\
\text { Question } \\
\text { s }\end{array}$ & $\begin{array}{l}\text { Age } \\
\text { Q1 }\end{array}$ & $\begin{array}{l}\text { Geographic } \\
\text { localization } \\
\text { s/Q4 }\end{array}$ & $\begin{array}{l}\text { Types } \\
\text { of } \\
\text { locatio } \\
\text { n/Q5 }\end{array}$ & $\begin{array}{l}\text { Knowledg } \\
\text { e about } \\
\text { GMOs/Q6 }\end{array}$ & $\begin{array}{l}\text { For or } \\
\text { against } \\
\text { GMOs/ } \\
\text { Q7 }\end{array}$ & $\begin{array}{l}\text { Influence of } \\
\text { information } \\
\text { transmitted } \\
\text { about } \\
\text { GMOs/Q8 }\end{array}$ & $\begin{array}{l}\text { Level of } \\
\text { difficulty } \\
\text { (tradition } \\
\text { al } \\
\text { vaccines) } \\
\text { / Q11 }\end{array}$ & $\begin{array}{l}\text { Level of } \\
\text { availability to } \\
\text { get edible } \\
\text { vaccines/Q14 }\end{array}$ \\
\hline Q1 & - & - & - & 0,000 & 0,001 & 0,163 & 0,459 & 0,000 \\
\hline Q4 & - & - & - & 0,646 & 0,300 & 0,449 & 0,188 & 0,002 \\
\hline Q5 & - & - & - & 0,593 & 0,874 & 0,481 & 0,301 & 0,043 \\
\hline Q6 & $\begin{array}{c}0,00 \\
0\end{array}$ & 0,646 & 0,593 & - & 0,430 & 0,001 & - & 0,610 \\
\hline Q7 & $\begin{array}{c}0,00 \\
1\end{array}$ & 0,300 & 0,874 & 0,430 & - & 0,113 & 0,676 & 0,000 \\
\hline Q8 & $\begin{array}{c}0,16 \\
3\end{array}$ & 0,449 & 0,481 & 0,001 & 0,113 & - & - & 0,052 \\
\hline Q11 & $\begin{array}{c}0,45 \\
9\end{array}$ & 0,188 & 0,301 & - & 0,676 & - & - & 0,111 \\
\hline Q14 & $\begin{array}{c}0,00 \\
0\end{array}$ & 0,002 & 0,043 & 0,610 & 0,000 & 0,052 & 0,111 & - \\
\hline
\end{tabular}

As we can see, in some chi-squared tests, we obtained a p-value less than 0,05 . Since these values are low, we can reject $\mathrm{HO}$ and conclude that those variables are dependent on each other. Analysing the values where our main variable - level of availability to get edible vaccines - is involved, we can conclude that it is associated with/dependent on age, geographic localizations, types of location and decision making - for or against GMOs. Thus, GMOs have a major role in this topic, and it is extremely important for people to be aware of their meaning and related studies in order to make a more thoughtful decision.

\subsubsection{Calculation of Pearson's correlation coefficients}

In order to check if the variables in some questions are linearly correlated, without grouping them, we selected the ones that are of most interest and, in SPSS, we calculated Pearson's correlation coefficients (table 4).

Table 4: Linear correlation coefficients between the values/variables of the corresponding selected questions

\begin{tabular}{|c|c|c|c|c|c|c|c|c|}
\hline $\begin{array}{c}\text { Variabl } \\
\text { es / } \\
\text { Questio } \\
\text { ns }\end{array}$ & $\begin{array}{l}\text { Age } \\
\text { / Q1 }\end{array}$ & $\begin{array}{c}\text { Geograph } \\
\text { ic } \\
\text { localizatio } \\
\text { ns/Q4 }\end{array}$ & $\begin{array}{c}\text { Types } \\
\text { of } \\
\text { locati } \\
\text { on/Q5 }\end{array}$ & $\begin{array}{c}\text { Knowled } \\
\text { ge about } \\
\text { GMOs/Q } \\
6\end{array}$ & $\begin{array}{c}\text { For or } \\
\text { again } \\
\text { st } \\
\text { GMO } \\
\text { s/ Q7 }\end{array}$ & $\begin{array}{c}\text { Influence } \\
\text { of } \\
\text { informati } \\
\text { on } \\
\text { transmitt } \\
\text { ed about } \\
\text { GMOs/Q } \\
8\end{array}$ & $\begin{array}{c}\text { Level of } \\
\text { difficulty } \\
\text { (tradition } \\
\text { al } \\
\text { vaccines) } \\
\text { / Q11 }\end{array}$ & $\begin{array}{c}\text { Level of } \\
\text { availability } \\
\text { to get edible } \\
\text { vaccines/Q1 } \\
4\end{array}$ \\
\hline Q1 & 1,00 & - & - & $-0,212$ & 0,092 & 0,005 & $-0,095$ & $-0,064$ \\
\hline Q4 & - & 1,00 & - & $-0,038$ & 0,091 & 0,033 & 0,107 & 0,001 \\
\hline Q5 & - & - & 1,00 & 0,050 & $\begin{array}{c}- \\
0,019\end{array}$ & $-0,018$ & $-0,024$ & $-0,064$ \\
\hline Q6 & $\begin{array}{c}- \\
0,21 \\
2\end{array}$ & $-0,038$ & 0,050 & 1,00 & 0,001 & $-0,140$ & - & 0,026 \\
\hline Q7 & $\begin{array}{c}0,09 \\
2\end{array}$ & 0,091 & $-0,019$ & 0,001 & 1,00 & 0,027 & $-0,059$ & $-0,242$ \\
\hline Q8 & $\begin{array}{c}0,00 \\
5\end{array}$ & 0,033 & $-0,018$ & $-0,140$ & 0,027 & 1,00 & . & $-0,009$ \\
\hline Q11 & $\begin{array}{c}- \\
0,09 \\
5\end{array}$ & 0,107 & $-0,024$ & $-0,054$ & $-0,059$ & 0,029 & 1,00 & 0,137 \\
\hline
\end{tabular}




\begin{tabular}{|c|c|c|c|c|c|c|c|c|}
\hline $\begin{array}{c}\text { Variabl } \\
\text { es / } \\
\text { Questio } \\
\text { ns }\end{array}$ & $\begin{array}{l}\text { Age } \\
\text { / Q1 }\end{array}$ & $\begin{array}{l}\text { Geograph } \\
\text { ic } \\
\text { localizatio } \\
\text { ns/Q4 }\end{array}$ & $\begin{array}{l}\text { Types } \\
\text { of } \\
\text { locati } \\
\text { on/Q5 }\end{array}$ & $\begin{array}{c}\text { Knowled } \\
\text { ge about } \\
\text { GMOs/Q } \\
6\end{array}$ & $\begin{array}{c}\text { For or } \\
\text { again } \\
\text { st } \\
\text { GMO } \\
\text { s/ Q7 }\end{array}$ & $\begin{array}{c}\text { Influence } \\
\text { of } \\
\text { informati } \\
\text { on } \\
\text { transmitt } \\
\text { ed about } \\
\text { GMOs/Q } \\
8\end{array}$ & $\begin{array}{l}\text { Level of } \\
\text { difficulty } \\
\text { (tradition } \\
\text { al } \\
\text { vaccines) } \\
\text { / Q11 }\end{array}$ & $\begin{array}{c}\text { Level of } \\
\text { availability } \\
\text { to get edible } \\
\text { vaccines/Q1 } \\
4\end{array}$ \\
\hline Q14 & $\begin{array}{c}- \\
0,06 \\
4\end{array}$ & 0,001 & $-0,064$ & 0,026 & $\begin{array}{c}- \\
0,242\end{array}$ & $-0,009$ & 0,137 & 1,00 \\
\hline
\end{tabular}

As we can see in table 2 , all values obtained in the selected questions present little or no linear correlation. Thus, there are weak linear correlations between the variables of questions 1 and 6, 4 and 11, 7 and 14,11 and 14 . However, since all of the coefficients are not close enough to 1 (positive correlation) or -1 (negative correlation), we can conclude that none of the factors that we questioned about - whether it was the age, the respondents' location, their knowledge about GMOs, the difficulty felt or not when administering traditional vaccines - affects, linearly, the availability of people to get edible vaccines. Not even the age factor significantly affects, linearly, the amount of knowledge or decision making for or against GMOs.

Hence, by analysing the correlation coefficient values, we can conclude that the availability of people to administer edible vaccines, asked in our main question (14), is linearly independent of any other factor questioned as well. Therefore, since this is a complex topic that needs national acceptance, it is very important not to have any factors interfering, in a linear way. Considering the suggestions made, the most crucial element in an easier implementation and acceptance is, in fact, the information transmitted. Individuals have the right to know every piece of correct information about this subject, which will allow them to decide whether they agree with this innovation or not and whether to get edible vaccines consciously.

\subsection{Interviews}

In addition to the online survey, we decided to conduct 15 interviews with health professionals so that more data could be collected. In the following table 5 we have outlined all 15 interviews by occupation, emphasizing certain aspects related to them.

Table 5: Data gathered from 15 interviews

\begin{tabular}{|c|c|c|c|c|c|c|}
\hline Occupation & $\begin{array}{l}\text { Number } \\
\text { of } \\
\text { interview } \\
\text { ees }\end{array}$ & $\begin{array}{l}\text { Gend } \\
\text { er }\end{array}$ & Ages & $\begin{array}{c}\text { Duration } \\
\text { of } \\
\text { career }\end{array}$ & $\begin{array}{l}\text { Place where } \\
\text { they work }\end{array}$ & Relevant opinions \\
\hline Nurses & 9 & $\begin{array}{c}100 \% \\
F\end{array}$ & $\begin{array}{l}23-58 \\
\text { years } \\
\text { old }\end{array}$ & $\begin{array}{c}5 \\
\text { months } \\
\text { and } \\
\text { between } \\
6 \text { and } 35 \\
\text { years }\end{array}$ & $\begin{array}{l}\text {-Health Center } \\
\text { Acute } \\
\text { Consultation; } \\
\text {-UCCI } \\
\text { Mealhada; } \\
\text {-Primary } \\
\text { Health Care- } \\
\text { Health Center; } \\
\text {-Mira Health } \\
\text { center; } \\
\text {-IPO Coimbra; } \\
\text {-Lamego } \\
\text { (ERPI); } \\
\text { - ACES Cávado } \\
\text { III } \\
\text { Barcelos / } \\
\text { Esposende; } \\
\text {-Local Health } \\
\text { Unit of } \\
\text { Matosinhos. }\end{array}$ & $\begin{array}{l}\text { "Provide training and } \\
\text { information to health } \\
\text { professionals on the } \\
\text { development and progress } \\
\text { in the creation of edible } \\
\text { vaccines." } \\
\text { "Success will depend on } \\
\text { transmitting sufficient } \\
\text { information to the general } \\
\text { public and the credibility of } \\
\text { this new procedure among } \\
\text { the scientific community." }\end{array}$ \\
\hline
\end{tabular}




\begin{tabular}{|c|c|c|c|c|c|c|}
\hline Occupation & $\begin{array}{l}\text { Number } \\
\text { of } \\
\text { interview } \\
\text { ees }\end{array}$ & $\begin{array}{l}\text { Gend } \\
\text { er }\end{array}$ & Ages & $\begin{array}{c}\text { Duration } \\
\text { of } \\
\text { career }\end{array}$ & $\begin{array}{l}\text { Place where } \\
\text { they work }\end{array}$ & Relevant opinions \\
\hline Doctors & 1 & $\begin{array}{c}100 \% \\
F\end{array}$ & $\begin{array}{l}58 \\
\text { years } \\
\text { old }\end{array}$ & 29 years & $\begin{array}{l}\text {-Local Health } \\
\text { Unit of } \\
\text { Matosinhos. }\end{array}$ & $\begin{array}{l}\text { "Probably the evolution } \\
\text { towards acceptance will be } \\
\text { rapid, due to the easier } \\
\text { administration and not } \\
\text { causing pain or discomfort } \\
\text { caused by the injectable." }\end{array}$ \\
\hline $\begin{array}{l}\text { Pharmacists/ } \\
\text { Researchers }\end{array}$ & 4 & $\begin{array}{l}50 \% \mathrm{~F} \\
50 \% \\
M\end{array}$ & $\begin{array}{l}23-38 \\
\text { years } \\
\text { old }\end{array}$ & $\begin{array}{c}1-15 \\
\text { years }\end{array}$ & $\begin{array}{l}\text {-Pharmacy; } \\
\text {-Chemistry } \\
\text { Center of } \\
\text { Coimbra / UC. }\end{array}$ & $\begin{array}{l}\text { "I am naturally skeptical of } \\
\text { edible vaccines. In my } \\
\text { opinion } \\
\text { there are alternatives } \\
\text { which can be carried out in } \\
\text { more effective and safer } \\
\text { ways, such as the } \\
\text { administration of intranasal } \\
\text { vaccines." } \\
\text { "I think it will be a very well } \\
\text { received innovation." }\end{array}$ \\
\hline $\begin{array}{c}\text { Student of } \\
\text { pharmaceutic } \\
\text { al engineering }\end{array}$ & 1 & $\begin{array}{l}100 \% \\
F\end{array}$ & $\begin{array}{l}21 \\
\text { years } \\
\text { old }\end{array}$ & $\begin{array}{l}4 \text { years } \\
\text { of the } \\
\text { course, } \\
\text { having } \\
\text { some } \\
\text { experien } \\
\text { ce }\end{array}$ & -FFUP. & $\begin{array}{l}\text { "I have certain doubts in } \\
\text { their development, namely } \\
\text { when it comes to the } \\
\text { phenomena of } \\
\text { contamination, the } \\
\text { possibility of food } \\
\text { interfering with the vaccine } \\
\text { administration..." }\end{array}$ \\
\hline
\end{tabular}

Observing table 5, the interviewees integrate the age range between 21 and 58 years old, and the information collected from all 15 interviews proves to be extremely relevant.

Considering the answers obtained from the nurses, we are able to conclude most of them are not aware of what edible vaccines are. Only four of them have knowledge about this type of vaccine, and two of them claim to only know the concept vaguely. They told us that the biggest difficulties in administering traditional vaccines are related to the needles, the associated pain, the higher cost (those that are not included in the national health plan), the displacement, the lack of information and trust, religious and ideological convictions, the transmission of fake news and the fact that almost every child is restless during the procedure. The solutions they presented to us are, in the case of children, to have games available, videos playing or awarding them with balloons or diplomas in order to distract them. Telling them that vaccines provide superpowers and that their idols (for example, football players) also take them can be a good option. For the older patients, nurses simply need to explain the importance of vaccines. Almost all of the nurses are in favor of edible vaccines, as long as their effectiveness is proven. Two of them needed more information to make a decision, since they did not know what edible vaccines are. They also told us that they think the acceptance will be easy, if all of the information about this innovation is provided to both health professionals and their direct users, because they are painless and easier to administrate. The skepticism and the lack of evidence of effectiveness were also mentioned as being the main reasons for a tough implementation. One of the nurses also claimed that the pharmaceutical industry may contest this innovative vaccine. Therefore, they suggested a few practices that, in their opinion, will lead to an easier implementation: provide more information, make them available for free and make the laboratories bet on the scientific development of these vaccines.

Regarding the doctor who responded to our survey, she already knew about this innovation and approved of it, because of its utility in underdeveloped countries and its benefits for the planet. The difficulties of administration and corresponding solutions mentioned by her are very similar to those the nurses referred to. 
She told us that the acceptance could be easy and that, once again, the lack of information could hinder its implementation.

Regarding pharmacists and researchers, just one of them had knowledge of what edible vaccines are. This individual revealed to be against them, since he thinks they have low credibility.

Considering that this innovation is easier to administer and avoids the adverse effects of traditional vaccines, the remaining respondents would be in favor of edible vaccines, if their pharmacological efficiency and safety of administration are proven. In these interviews, the access to appropriate spaces for administration purposes, the necessary materials, the fact that it is an intravenous administration and possible allergic reactions at the administration site were some of the difficulties in administering the traditional vaccines presented by the interviewees. The solutions, when it comes to the barriers previously mentioned, are understandably related to the transference to a Health Center, in case the health professionals do not have the necessary conditions to administer them, choose soft spots to administer the vaccines and make the pleats correctly and also advise the measures to be taken in case of allergic reaction. The pharmacists and researchers also informed us that it will be easy to accept this technology, depending on the price (if these vaccines are presented with a fair one, it can help with their acceptance) and if their effectiveness is proven. One of them also added that clinical studies are very time-consuming and expensive. Another suggestion was that these vaccines should have the State's contribution, in case they are expensive, and that they must be well studied before their implementation.

Lastly, in order to add the opinion of a student who is about to enter the labor market, we decided to interview a pharmaceutical engineer to be, who had very little knowledge about edible vaccines, expressing doubts about their development. The difficulties of administration and the solutions mentioned by her were identical to those referred previously by health professionals. She believes that these innovative vaccines will be easy to implement, but that the contamination phenomena can make this difficult.

Comparing the responses obtained from the online survey and the interviews, we realize they pursue a common goal: the transmission of information about these vaccines and proof of their effectiveness. These are the most important factors, both mentioned by professionals and users, thus allowing a global acceptance of edible vaccines.

Once we realize so few individuals are aware of this topic and the research behind it, our intent is no longer to just identify benefits and barriers of this innovation. Since it is a perfectly legitimate new form of a vaccination, this paper contributes to enlighten several individuals of different age groups and locations, in order for them to have a concrete idea of what may arise in the near future. This subject can be a bit controversial, due to the clear lack of general knowledge on this matter and the fact that it is unaddressed by many health professionals.

It is necessary to create and transmit more knowledge about this topic, since it represents a major innovation, carrying many benefits for society in general. In order to keep people informed and aware of how technology is changing, hopefully improving, with practices that are vital for our survival and which may increase the average life expectancy, the field of medicine and health has to develop any means that bring society closer to their findings.

\section{Conclusion}

The present article is an exploratory study that produces valid knowledge about an important and promising innovation in the health area: edible vaccines. Discovering knowledge and generating knowledge are the first steps in the knowledge management cycle (Jashapara, 2004).

Through the participation of the 15 health-professional interviewees and the adherence of 370 individuals to the survey, it was possible to draw conclusions and map out suggestions, specified in this section.

Interestingly, and as stated above, interviewee nurses told us that there are significant difficulties in administering traditional vaccines - including related to the needles, the associated pain, the higher cost, the displacement, the lack of information and trust, religious and ideological convictions, and the fact that almost all children are restless during the procedure. Thus, we see a need for edible vaccines. 
The pandemic COVID-19 we are currently experiencing proved to be a barrier regarding contact with professionals in person. Their time to reply to the survey was limited due to the complexity of the situation, and a face-to-face conversation was not always possible.

Regardless of all of the complications in the process of developing it, this article advances the study and can contribute to the general insight of this innovative method. Furthermore, this paper allows an improvement of knowledge in the field of medicine and health. Since this theme is still waiting to be explored and invested in, the present article allows its readers to comprehend the technical part involved, as well as to draw conclusions from the results suggested by our research: there may be a broader acceptance of this type of vaccine than previously thought.

Therefore, it seems possible, as implied by the literature review and the perceptions and suggestions we obtained, to evolve and create more knowledge around edible vaccines.

In terms of major conclusions, we are able to infer that the general knowledge about Genetically Modified Organisms (GMO) is associated with the information provided by the media about them, for example, related to food - genetic changes in corn, beta carotene rice, among others, as already expected. Another interesting finding is related to the fact that the level of willingness to get an edible vaccine depends on being in favor or against GMO's. The fact that the propensity of our sample to take edible vaccines is not linearly dependent on any factor, as we can see by looking at the results, is very positive, meaning individuals are prone to including these in their lives.

The clearest finding of this study is that a correct distribution of information about these vaccines (or the effective management of knowledge dissemination) and the proof of the edible vaccines' effectiveness are of the utmost urgency, especially if we want people to welcome this method of vaccination and, further ahead, use it. The fact that, for example, only one of the pharmacists and researchers had knowledge about the edible vaccine topic, made us realize that this needs to be further explored and brought to light. Therefore, the present study urges us to suggest to the interested industry to improve its marketing communication, by transmitting more and accurate information about studies related to edible vaccines. The state of progress regarding edible vaccines needs to be brought to the public in newscasts, science papers, magazines, health centers and hospitals.

The opinions we gathered, from both health professionals and the public in general, turned out to be useful and constructive, enabling us to comprehend in what ways this innovative vaccine can act and be valuable to our society. Their suggestions, essentially related to the transmission of more and qualified information about this topic, can represent some of the paths to take in order to prove that this innovation is, in fact, the key to overcome many of the restrictions found when considering injections, most of which are related to fear, pain, possible secondary side effects and waste.

Management innovations are implemented with the purpose of improving the performance of a company or industry (Panwar et al, 2018). In this specific case, we are convinced that the health and pharmaceutical industry can benefit from the acceptance and implementation of edible vaccines, since this opposes some of the previously mentioned restrictions. We must also highlight that scientific advances, when based on innovation, are one of the major sources of economic growth (Chaminade and Lundvall, 2019).

A business process innovation is a completely new process, or an improved one, that differs significantly from the previous business processes (Perani, 2019, based on the Oslo Manual). Admitting that edible vaccines undoubtedly fit into this description, we are certain that this article can contribute to the enlightenment of this existing innovative form of vaccines - edible ones - this being a very promising innovation in the health sector in the near future. Furthermore, we believe our research can serve as a reference point and call to action for science and health practitioners in the field.

\section{Future studies}

In future studies, this subject can be further investigated, both in terms of research and proof of the effectiveness of edible vaccines, as well as continuing to assess people's knowledge of them and the propensity to choose this innovation, instead of traditional vaccines. 
Furthermore, it would be interesting to extend this study, in order to comprehend the reasons behind the individuals' opinions and predispositions, when it comes to the subject.

It is also very important to keep on creating content on this topic, in order to raise people's awareness and improve their knowledge. Future researchers on the topic could also opt for an approach that could get them closer to the experts in the field, in order to boost credibility in this sort of vaccination. Future research could also increase the sample size in the field work when addressing the topic.

\section{Acknowledgements}

We would like to thank all of the participants of the survey we developed. The University of Aveiro and DEGEIT are also worthy to be mentioned in this section, for granting us invaluable access to the databases used, crucial for the development of this article.

\section{References}

Abubakar, A. M., Elrehail, H., Alatailat, M. A., and Elçi, A., 2019. Knowledge management, decision-making style and organizational performance. Journal of Innovation \& Knowledge [e-journal], 4(2), pp.104 - 114. https://doi.org/10.1016/j.jik.2017.07.003.

Bayer, 2019. Benefits of GMOs and Biotechnology - Bayer [online]. Available at: <ttps://www.bayer.com/en/crop-scienceinnovations-biotech-gmos.aspx> [Accessed 2 June 2020].

Bryman, A., Bell, E., 2015. Business research methods 4th edition. Oxford, UK: Oxford University Press.

Carvalho, H.G., Roberto dos Reis, D. and Beatriz Cavalcante, M., 2011. Gestão da inovação [e-book]. Curitiba: Aymará Educação. Available through: Repositório Institucional da Universidade Tecnológica Federal do Paraná website <http://repositorio.utfpr.edu.br/jspui/handle/1/2057> [Accessed 2 June 2020].

Chaminade, C., and Lundvall, B., 2019. Science, technology, and innovation policy: old patterns and new challenges [ebook]. Oxford: Oxford Research Encyclopedia of Business and Management. Available through: Oxford Research Encyclopedia website <https://doi.org/10.1093/acrefore/9780190224851.013.179> [Accessed 26 May 2020].

Choi, B., and Lee, H., 2002. Knowledge management strategy and its link to knowledge creation process. Expert Systems with Applications, [e-journal] 23(3), pp.1 - 2. https://doi.org/10.1016/S0957-4174(02)00038-6.

Criscuolo, E., Caputo, V., Diotti, R. A., Sautto, G. A., Kirchenbaum, G. A., and Clementi, N., 2019. Alternative methods of vaccine delivery: an overview of edible and intradermal vaccines. Journal of Immunology Research [e-journal], 2019(Special Issue), pp.1 - 13. https://doi.org/10.1155/2019/8303648.

Del Rio, C., and Malani, P. N., 2020. COVID-19 - New insights on a rapidly changing epidemic, JAMA [e-journal], 323(14), pp.1339 - 1340. https://doi.org/10.1001/jama.2020.3072.

Fonseca, M.S., Varela, M.A.L.N., Frutuoso, A., and Monteiro, M.F.F.R.P., 2018. Vaccine refusal in an urban area of northern Portugal. Scientia Medica [e-journal], 28(4), pp.1 - 8. https://doi.org/10.15448/1980-6108.2018.4.32152.

Frumkin, H., Bratman, G.N., Breslow, S.J., Cochran, B., Kahn, P.H., Lawler, J.J., Levin, P.S., Tandon, P.S., Varanasi, U., Wolf, K.L., and Wood, S.A., 2017. Nature contact and human health: A research agenda. Environmental Health Perspectives [e-journal], 125(7), pp.1 - 18. https://doi.org/10.1289/EHP1663.

Gates, B., 2020. Responding to Covid-19 - A once-in-a-century pandemic? The New England Journal of Medicine [e-book], 382(18), pp.1677 - 1679. https://doi.org/10.1056/NEJMp2003762.

Grimsdottir, E. and Edvardsson, I. R., 2018. Knowledge management, knowledge creation, and open innovation in Icelandic SMEs. SAGE Open [e-journal], 8(4), pp.1 - 13. https://doi.org/10.1177/2158244018807320.

Gunasekaran, B. and Gothandam, K., 2020. A review on edible vaccines and their prospects. Journal of Medical and Biological Research [e-journal], 53(2), 1-10. https://doi.org/10.1590/1414-431x20198749.

Iliev, I., Gajdosov, A., Libiakova G. and Jain S., 2010. Plant micropropagation. In: M. R. Davey \& P. Anthony, eds. 2010. Plant Cell Culture: essential methods. Chichester, UK: John Wiley \& Sons, pp.1-24.

Jashapara, A., 2004. Knowledge management: An integrated approach. Harlow: Pearson Education.

Khan, K.H., 2013. DNA vaccines: roles against diseases. Germs [e-journal], 3(1), pp.26 - 35. https://doi.org/10.11599/germs.2013.1034.

Kurup, V. M., and Thomas, J., 2019. Edible vaccines: promises and challenges. Molecular biotechnology [e-journal], 62(3), pp.79 - 90. https://doi.org/10.1007/s12033-019-00222-1.

Lajoso, J., Sousa, A., Albuquerque, J., Mineiro, R., Au-Yong-Oliveira, M., 2020. Closed Against Open Innovation: A Comparison Between Apple and Xiaomi. Á. Rocha et al. (Eds.), Advances in Intelligent Systems and Computing (Book of the AISC series), Vol. 1159, Springer Nature Switzerland AG, pp. 436-448.

Machado, A., Torres, A.R., Kislaya, I., and Neto, M., 2019. Vacinação antigripal da população Portuguesa, em 2016/2017 e 2017/2018: cobertura e características do ato vacinal. Lisboa: Instituto Nacional de Saúde.

McInerney, C., Bird, N., and Nucci, M., 2004. The flow of scientific knowledge from lab to the lay public: the case of genetically modified food. Science Communication [e-journal], 26(1), pp.44 - 74. https://doi.org/10.1177/1075547004267024. 
Melnick, J.L., 1978. Advantages and disadvantages of killed and live poliomyelitis vaccines. Bulletin of the World Health Organization, [e-journal] 56(1). Available through: Europe PMC website $<$ https://europepmc.org/article/pmc/pmc2395534> [Accessed 3 June 2020].

Melo, C. S. A., 2019. A gestão do conhecimento e o processo de inovação de medicamento: estudo de caso em uma indústria farmacêutica nacional de grande porte. MCs. Instituto de Tecnologia em Fármacos/Farmanguinhos. Available at: <https://europepmc.org/article/pmc/pmc2395534> [Accessed 29.05.2020].

Merchant, N., 2013. Sitting Is The Smoking Of Our Generation. Harvard Business Review [e-journal]. Available through: Harvard Business Review website <https://hbr.org/2013/01/sitting-is-the-smoking-of-our-generation> [Accessed 14 October 2020].

Nelson, C.H., 2001. Risk perception, behavior, and consumer response to genetically modified organisms: toward understanding american and european public reaction. American Behavioral Scientist [e-journal], 44(8), pp.1371 1388. https://doi.org/10.1177/00027640121956737.

North, K., and Kumta, G., 2018. Knowledge management: Value creation through organizational learning. Switzerland: Springer International Publishing AG.

Ordeanu, V., 2018. The strategic importance of vaccination for national defense and security. Romanian Journal of Military Medicine, [e-journal] 121(3). Available through: Revista de Medicină Militară website <http://www.revistamedicinamilitara.ro/wp-content/uploads/2018/12/RJMM-vol-CXXI-nr-3-din-20182.pdf\#page $=40>$ [Accessed 20 May 2020].

Orenstein, W.A., Bernier, R.H., Dondero, T.J., Hinman, A.R., Marks, J.S., Bart, K.J., and Sirotkin, B., 1985. Field evaluation of vaccine efficacy. Bulletin of the World Health Organization, [e-journal] 63(6), 1055-1068. Available through: Europe PMC website <https://europepmc.org/article/pmc/pmc2536484> [Accessed 3 June 2020].

Orenstein, W.A., and Ahmedb, R., 2017. Simply put: vaccination saves lives. Proceedings of the National Academy of Sciences of the United States of America [e-journal], 114(16), pp.4031 - 4033. https://doi.org/10.1073/pnas.1704507114.

Panwar, A., Jain, R., Rathore, A.P.S., Nepal, B., Lyons, A.C., 2018. The impact of lean practices on operational performance an empirical investigation of indian process industries. Production Planning \& Control [e-journal], 29(2), pp.158 - 169. https://doi.org/10.1080/09537287.2017.1397788.

Patlas, M.N., 2020. COVID-19: What can we Learn from Stories from the trenches? Canadian Association of Radiologists Journal [e-journal], 71(2), pp.125 - 126. https://doi.org/10.1177/0846537120913497.

Perani, G., 2019. Business innovation statistics and the evolution of the Oslo Manual. NOvation: Critical Studies of Innovation, [e-journal] 1(2019). Available through: Researchgate website $<$ https://www.researchgate.net/publication/335340331 Business innovation statistics and the evolution of the Oslo Manual> [Accessed 15 July 2020].

Pinto, R.S., 2018. Vacinação obrigatória: saúde pública versus discricionariedade parental. MCs. Universidade do Porto.

Pinto, E. F., Matta, N. E., and Da-Cruz, A. M., 2011. Vacinas: progressos e novos desafios para o controle de doenças imunopreveníveis. Acta Biologica Colombiana [e-journal], 16(3). Available through: Researchgate website $<$ https://www.researchgate.net/publication/235678251 VACINAS PROGRESSOS E NOVOS DESAFIOS PARAO CON TROLE DE DOENCAS IMUNOPREVENIVEIS> [Accessed 16 April 2020].

Porter, M.E., 1990. The competitive advantage of nations. Harvard Business Review, March-April, pp.73-91.

Québec, G., 2020. OGM: principales cultures GM [online]. Available at $\leq$ http://www.ogm.gouv.qc.ca/ogm chiffres/principales cultures.html> [Accessed 26 May 2020]

Santos, P., and Hespanhol, A., 2013. Recusa vacinal - o ponto de vista ético. Revista Portuguesa de Clínica Geral, [e-journal] 29(5), pp.328 - 333. https://doi.org/10.32385/rpmgf.v29i5.11167.

Saunders, M., Lewis, P., Thornhill, A., 2016. Research methods for business students. 7th edition. Harlow: Pearson Education.

Schatzmayr, H.G., 2003. Novas perspetivas em vacinas virais. História, Ciências, Saúde-Manguinhos, [e-journal] 10(2), pp.655 - 669. https://doi.org/10.1590/S0104-59702003000500010.

Schilling, M., 2017. What's your best innovation bet? By mapping a technology's past, you can predict what future customers will want. Harvard Business Review, [e-journal] 95(4). Available through: Harvard Business School website $<$ https://hbr.org/2017/07/whats-your-best-innovation-bet> [Accessed 1 June 2020].

Subtil, C., and Vieira, M., 2011. Os primórdios da organização do Programa Nacional de Vacinação em Portugal. Revista de Enfermagem Referência, [e-journal] III Série(4). Available through: Scielo Portugal website $<$ http://www.scielo.mec.pt/scielo.php?script=sci arttext\&pid=S0874-02832011000200018> [Accessed 26 May 2020].

Sun, DW., 2018. Modern Techniques for food authentication. Dublin, Ireland: Academic Press.

The Organisation for Economic Co-operation and Development, 2019. Health in the 21st Century. In: High-Level Policy Forum on Sustainable Development. Copenhagen, Denmark, 9-18 July 2019.

Little, T. A., and Deokar, A. V., 2016. Understanding knowledge creation in the context of knowledge-intensive business processes. Journal of Knowledge Management, [e-journal] 20(5), pp.858 - 879. https://doi.org/10.1108/JKM-112015-0443.

Whitesides, G. M., 2014. O início: Responsabilidade global em saúde - com foco em doenças tropicais. Journal of the Brazilian Chemical Society, [e-journal] 25(10), pp.1755 - 1758. https://dx.doi.org/10.5935/0103-5053.20140236. 
World Health Organization, 2014. Frequently asked questions on genetically modified foods. [online] Available at: <https://www.who.int/foodsafety/areas work/food-technology/faq-genetically-modified-food/en/> [Accessed 16 May 2020].

World Health Organization, 2019. Immunization coverage. [online] Available at: <https://www.who.int/en/newsroom/fact-sheets/detail/immunization-coverage> [Accessed 2 July 2020].

World Health Organization, 2020. Coronavirus disease (COVID-19): Vaccine research and development. [online] Available at: https://www.who.int/news-room/q-a-detail/coronavirus-disease-(covid-19)-vaccine-research-and-development [Accessed 1 November 2020].

Wunderlich, S., and Gatto, K.A., 2015. Consumer perception of genetically modified organisms and sources of information. Advances In Nutrition, [e-journal] 6(6) pp.842 - 851. https://doi.org/10.3945/an.115.008870. 